\title{
Cause of Recurrent Abdominal Pain: Incidental Intestinal Nonrotation
}

\section{Tekrarlayan Karın Ağrısının Bir Nedeni: İnsidental Intestinal Nonrotasyon}

\author{
(1) Ramazan Tiken \\ Lokman Hekim Akay Hospital, Deparment of Radiology Ankara, Turkey \\ Copyright@Author(s) - Available online at www.dergipark.org.tr/tr/pub/medr \\ Content of this journal is licensed under a Creative Commons Attribution-NonCommercial 4.0 International License.
}

\begin{abstract}
Intestinal nonrotation is a subtype of malrotation and it is usually detected incidentally in adulthood. Although nonrotation is often asymptomatic, patients with this condition are at increased risk of conditions that may require emergency surgery, such as intestinal obstruction and necrosis. In relation to our case of a 52-year-old male patient diagnosed with intestinal nonrotation in radiological examinations performed for renal colic, the current status in the literature was discussed. In conclusion, in cases of intestinal nonrotation, radiologists and surgeons should be alert to this possibility as the diagnosis and treatment processes will be affected.

Keywords: Intestinal nonrotation; malrotation; abdominal pain; computed tomography

Öz

İntestinal nonrotasyon, malrotasyonun bir alt tipidir ve genellikle erişkin dönemde tesadüfen tespit edilir. Nonrotasyon genellikle asemptomatik olmasına rağmen, bu hastalar, ileus ve nekroz gibi acil cerrahi gerektirebilecek durumlar açısından yüksek risk altındadır. Olgumuzda renal kolik nedeniyle yapılan radyolojik incelemelerde intestinal nonrotasyon tanısı alan 52 yaşında erkek hastanın literatüre ışığında mevcut durumu tartışıldı. Sonuç olarak, intestinal nonrotasyon varlığında tanı ve tedavi süreci etkileneceğinden radyologlar ve cerrahlar bu duruma karşı uyanık olmalıdır.
\end{abstract}

Anahtar Kelimeler. Intestinal nonrotasyon,malrotasyon, karın ağrısı, bilgisayarlı tomografı

\section{INTRODUCTION}

Intestinal nonrotation is a congenital anomaly that may present with ischemia and volvulus in the childhood and neonatal period. Intestinal nonrotation is characterized by the small bowel loops being located mainly in the right half of the abdomen and the colon in the left half of the abdomen. It is considered a subtype of malrotation, which is described as the abnormal localization of the small and large intestine segments in the abdomen (1). It is a very rare anomaly that occurs through an error in bowel rotation in the second and third periods of the embryological period $(2,3)$. In the adult period, nonspecific symptoms may present such as nausea, vomiting, and recurrent abdominal pain, as well as symptoms that require urgent surgery, such as intestinal obstruction and necrosis (4). The presence of intestinal nonrotation should be known before the surgical procedure like other structural anomalies (5).

In this case report, we describe the X-ray and computed tomography (CT) findings of intestinal non-rotation together with findings in the literature.

\section{CASE PRESENTATION}

A52-year-old male presented to theemergency department with complaints of nausea, vomiting, and abdominal pain. In his history, it was learned that he had visited emergency services with occasional abdominal pain. A physical examination revealed no pathological findings, except for abdominal tenderness and left flank pain. Laboratory tests showed no abnormality, except for c-reactive protein at 10 $\mathrm{mg} / \mathrm{dL}$. Colon gas was not observed on the right in the standing direct abdominal X-ray. Colon loops filled with feces were found to be located in the left quadrant (Figure 1). Because of the persistence of nausea and vomiting 
and symptoms that could not be clearly explained, an abdominal CT was performed by administering contrast material through the vascular access. Using CT, a $5 \mathrm{~mm}$ kidney stone was observed in the lower pole of the left kidney (Figure 2). It was observed that the colon loops and appendix were located in the left lower quadrant, while the small bowel loops were predominantly located in the right half of the abdomen. It was also observed that the superior mesenteric artery was located on the right side of the superior mesenteric vein (Figures 3A, 3B, 3C).

The patient's left kidney stone was a cause of renal colic,and the diagnosis of intestinal nonrotation was confirmed incidentally. After six hours of observation the patient was discharged, as abdominal discomfort was relieved and nausea and vomiting had regressed.

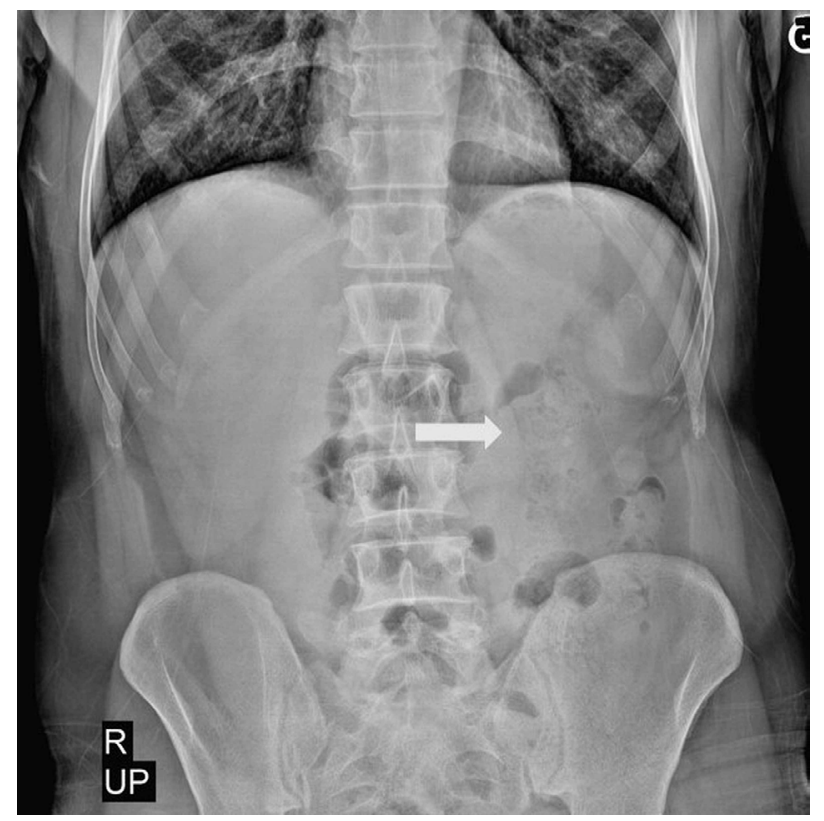

Figure 1. 52-year-old male patient. A direct abdominal radiograph (arrow) shows intestinal rings with fecal residue in the left half of the abdomen.

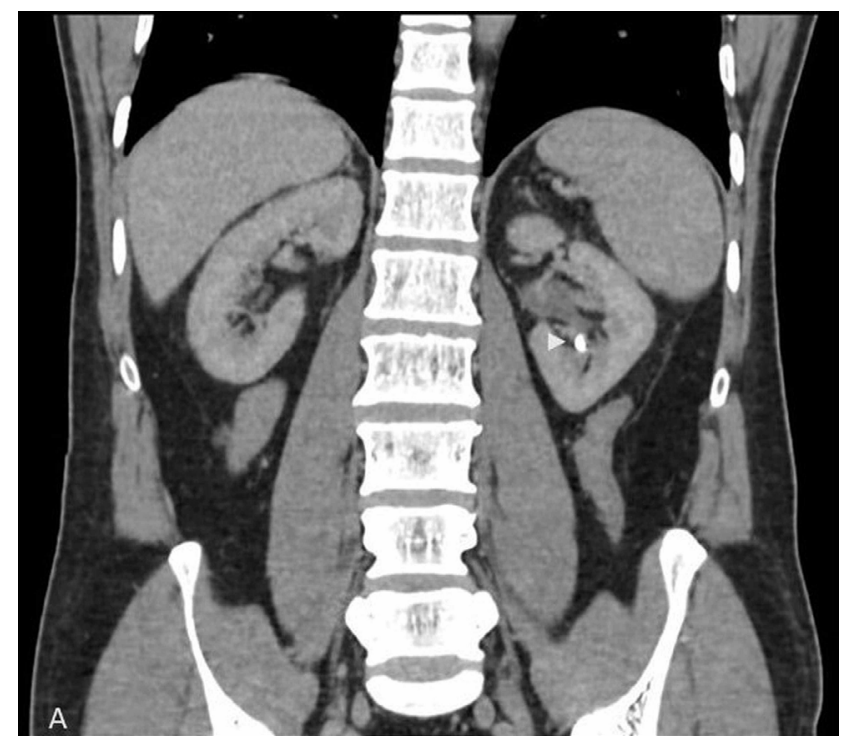

Figure 2. Coronal post-contrast computed tomography image shows a stone (arrowhead) in the lower pole of the left kidney.

\section{DISCUSSION}

Intestinal nonrotation is a subtype of malrotation characterized by the small intestine being located on the right side of the abdomen, with a higher risk of volvulus, and the colon loops being located on the left side of the abdomen (1). During fetal development, the midgut herniates to the umbilical stalk in the sixth week and rotates 90 degrees counterclockwise around it. Then, by the tenth week, with an additional 180 degrees counterclockwise rotation, it completes a 270-degree rotation. An abnormality that may occur at this stage can result in nonrotation, malrotation, or reverse rotation. In the case of nonrotation, the first 90 degrees counterclockwise rotation is completed, but there is no additional rotation when the midgut returns to the abdominal cavity. As a result, the small intestines form to the right of the midline and the colon to the left (6).

While intestinal malrotation often presents through symptoms in pediatric patients, it generally does not do so in adults and is rarely diagnosed at an advanced age (7). It can cause recurrent abdominal pain, malabsorption, and vomiting in adults. Since nonrotation can be seen incidentally through routine radiological imaging, especially in adult patients, clinicians and radiologists should be aware of this situation (8).

Nonrotation usually presents with recurrent abdominal pain, appearing as nonspecific pain anywhere in the abdominal area. The pain is initially managed conservatively and then through surgical correction. A patient with symptoms of recurrent abdominal pain should exclude intestinal malrotation as a reason (7). Such patients have an increased risk of bowel obstruction, acute or chronic volvulus, and intestinal necrosis. In our case, the patient'sintestinal nonrotation was diagnosed incidentally through radiological examination.

In the case of nonrotation, the appendix and cecum are localized on the left, so diseases affecting this region may not present with typical symptoms, which can mislead diagnosis, so radiologists and surgeons should be alert to this possibility. Gastrointestinal anomalies such as nonrotational jejunal and duodenal atresia, omphalocele, gastroschisis, congenital diaphragmatic hernias, and heterotaxy syndrome may accompany intestinal nonrotation (9). Although plain radiography cannot specifically diagnose intestinal nonrotation, the absence of colon loops filled with stool in the right lower quadrant and the presence of jejunal loops located in the right lower quadrant may indicate nonrotation (10). Additionally, ultrasound is used in the diagnosis of urinary system pathologies, it may be insufficient for the diagnosis of malrotation (11).

CT not only shows malposition but also reveals extraintestinal findings such as the abnormal relationship between the superior mesenteric artery and the superior mesenteric vein, which is a useful indicator of malrotation (12). 


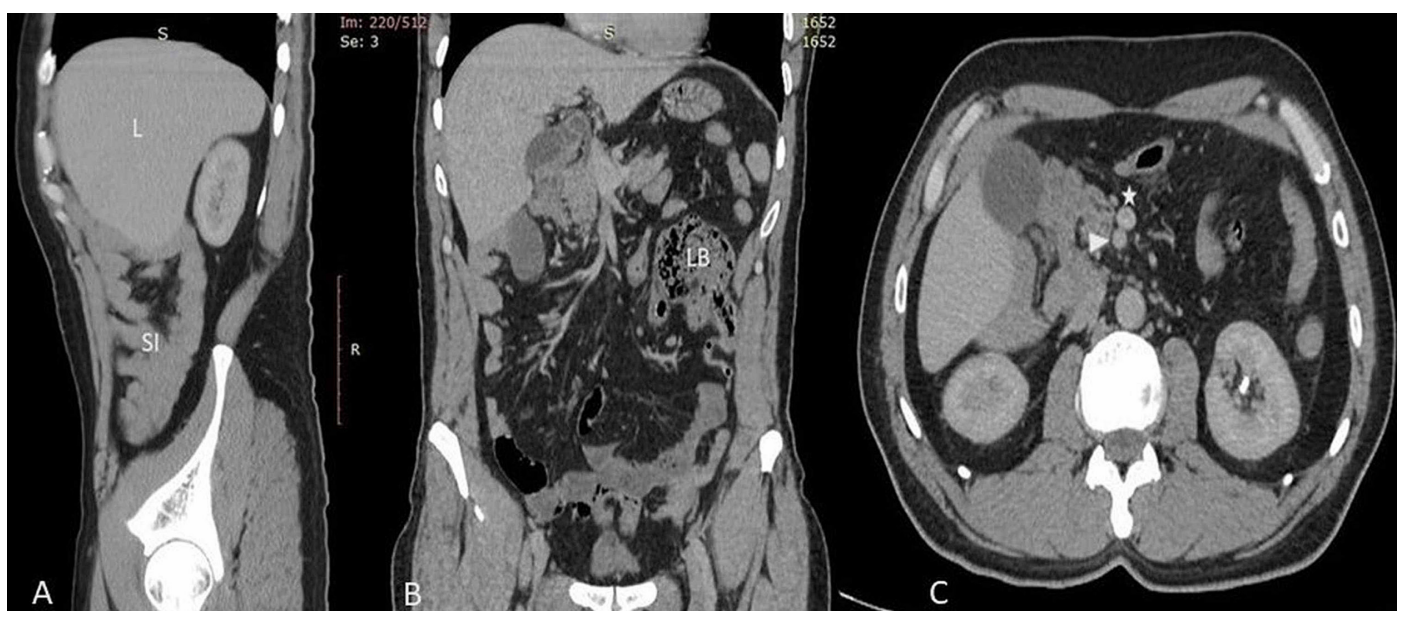

Figure 3. Computed tomography shows signs of intestinal nonrotation. A, B : Coronal, and parasagittal post-contrast computed tomography images show that the appendix and all colon loops are predominantly located in the left lower quadrant (L: liver, SI: small intestine, LB: large bowel). C: In the axial post-contrast computed tomography image, the superior mesenteric artery (arrowhead) is visible to the right of the superior mesenteric vein (asterisk)

\section{CONCLUSIONS}

Since nonrotation may present through symptoms such as recurrent abdominal pain, nausea, and vomiting,radiologists and surgeons should be watchful during radiological examinations performed for any reason due to the risk of ischemia and volvulus in the presence of intestinal nonrotation,even in asymptomatic cases. In addition, the embryology and anatomy of the midgut should be well understood. Surgeons should also pay attention to clinical appearance since the appendix, colon, and small intestine locations are different from normal in cases of intestinal nonrotation. During surgery, care should be taken as the surgical procedure will vary according to the anatomical location of the organ.

Financial disclosures: All authors report no financial interests or potential conflicts of interest.

Conflict of Interest: The authors declare that they have no competing interest.

Informed Consent: Informed consent was taken from the patient.

\section{REFERENCES}

1. Applegate KE, Anderson JM, Klatte EC. Intestinal malrotation in children: a problem-solving approach to the upper gastrointestinal series. Radiographics 2006;26:1485-1500.

2. Torres AM, Ziegler MM. Malrotation of the intestine. World $\mathrm{J}$ Surg 1993;17:326-31.

3. Ballesteros Gómiz E, Torremadé Ayats A, Durán Feliubadaló $C$, et al. Intestinal malrotation--volvulus: imaging findings. Radiologia 2015;57:9-21.
4. von Flüe M, Herzog U, Ackermann C, et al. Acute and chronic presentation of intestinal nonrotation in adults. Dis Colon Rectum 1994;37:192-8.

5. Gürün E, Akdulum İ. A rare congenital anomaly of mediastinal vascular structures; isolated retroaortic left brachiocephalic vein. J. Health Sci Med. 3:499-502.

6. Gupta AC, Herts B. Heterotaxia with Polysplenia. J Urol 2015;194:801-2.

7. Nehra D, Goldstein AM. Intestinal malrotation: varied clinical presentation from infancy through adulthood. Surgery 2011;149:386-93.

8. Dilley AV, Pereira J, Shi EC, et al. The radiologist says malrotation: does the surgeon operate?. Pediatr Surg Int 2000;16:45-9.

9. Fukuya T, Brown BP, Lu CC. Midgut volvulus as a complication of intestinal malrotation in adults. Dig Dis Sci 1993;38:43844.

10. Khatami A, Mahdavi K, Karimi MA. Ultrasound as a feasible method for the assessment of malrotation. Pol J Radiol. 2014;79:112-6.

11. Akdulum İ, Akyüz M, Gürün E, et al. The Change in the Renal Pelvis Anterior-Posterior Diameter Between Prevoiding and Postvoiding Status, and Its Correlation With Vesicoureteral Reflux. Ultrasound Q 2020;36:371-4.

12. Pickhardt $P J$, Bhalla $S$. Intestinal malrotation in adolescents and adults: spectrum of clinical and imaging features. AJR Am J Roentgenol 2002;179:1429-35. 